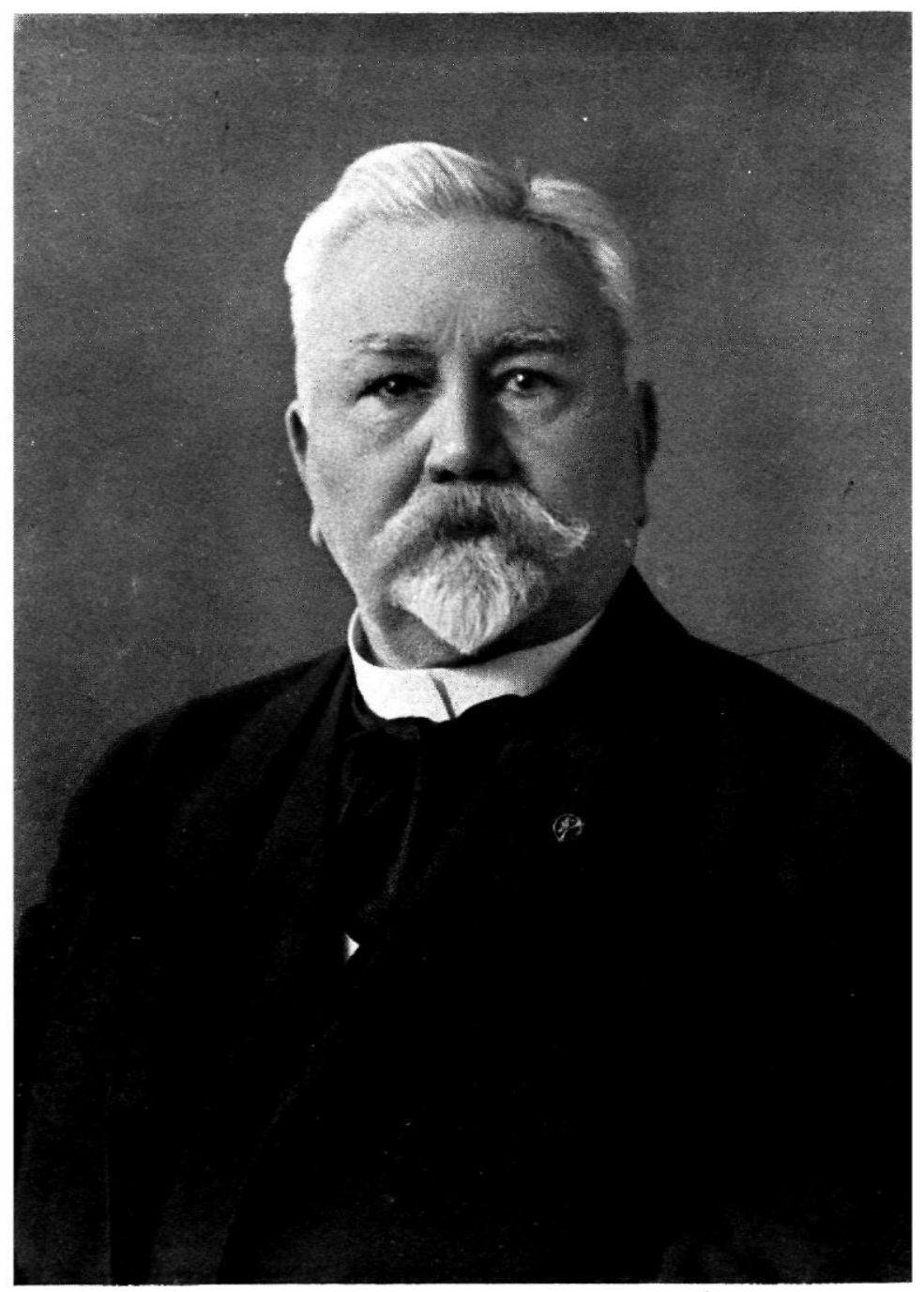




\section{TER GEDACHTENIS AAN Dr. J. W. IJZERMAN (1851-1932).}

(Met portret).

I.

In de laatste jaren zijns levens een krasse oude heer, wiens zilverwit haar contrastreerde met de bruine oogen, waarin het oude vuur nog tintelde. Een korte, gezette gestalte, stevig in de schouders; verzorgd, maar altijd eenvoudig gekleed. Vriendelijk, maar afgemeten. Tot het laatste toe in zaken, doch daarnaast onafgebroken bezig met de studie van landen en volken, waarvan hij de mede-ontdekker was geweest. Zoo deed hij, verbonden als zijn naam was aan de uitgaaf der journalen, betrekking hebbend op de Eerste Schipvaart der Hollanders op Oost-Indië, denken aan een der ,bewindhebbers ende versorgers van de gansche saecke”, mannen van de ,opkomst van het Nederlandsch gezag", dienaar eerst, mede-beheerder naderhand. Man van de daad, bedaard bij het overleg, doortastend in de uitvoering; voorzichtig maar, als het pas gaf, alle kracht inzettend; zeker van zichzelf, zijne waarde zich ten volle bewust, maar rustig zich beheerschend; geduldig in het aanhooren, snel van beslissing; iemand, op wiens woord men aankon, en die, zonder veel te zeggen, blijmoedig vooraan ging. Een geboren ,leider van mannen”.

Maker van zijn lot, bouwmeester eerst aan groote werken, medebewindvoerder van een wereldbedrijf, was IJzerman voortgekomen uit eenvoudigen stand en gevormd in een strenge leerschool, de Militaire Academie te Breda. In 1870 werd hij 2e luitenant bij het corps ingenieurs, mineurs en sappeurs. In die jaren heeft hij leeren dienen en optreden; zelfbeheersching moet hem aangeboren zijn geweest, de militaire tucht heeft die bevorderd. Scherpzinnigheid, opmerkingsgave lag in zijn wakkeren geest. Voor de knappe koppen aan de Militaire Academie lag de toekomst: voor den een in rechte lijn bij de Genie in Nederland, fortenbouw in het polderland, naderhand deelnemen aan het politieke leven, opklimmen tot een der hoofdmannen van de liberale partij; voor den ander in een nieuwe richting, waar, al was het in een vreemd land, zijn geest en hand mooi werk zou vinden, 
en zijn energie hem vooruit zou brengen, tot carrière en, zoo mogelijk, fortuin.

Toen in Nederland personeel werd gevraagd voor eene opneming ter Westkust van Sumatra, waarmede belast was de Ingenieur J. L. Cluysenaer tot het instellen van onderzoekingen naar de beste gelegenheid om op Sumatra spoorwegen aan te leggen, zoo ter verbetering van het transportstelsel in het Gouvernement Sumatra's Westkust in het algemeen, als in het bijzonder voor den afvoer van steenkolen uit de Padangsche Bovenlanden naar de kust, meldde onder meer anderen zich aan IJzerman. Ook hij werd aangenomen, hoewel eigenlijk nog te jong voor clat dienstverband.

II.

1873. „Er waren nog geen donkere Atjeh-wolken aan den politieken gezichtseinder gerezen. Niemand dacht nog aan de zorgen, die een naburig vijand baren zou", aldus leidde Busken Huet dat jaar in. Het was gedurende de landvoogdij van Mr. James Loudon, de dageraad van een nieuwen tijd voor Indië, waarvan ieder de schoonste verwachtingen had. Java had toen al zijn eerste spoorwegen, BataviaBuitenzorg en Samarang-Vorstenlanden, aangelegd door particuliere maatschappijen met rentegarantie van staatswege. Dat was bereikt ,ten spijt van de conservatieve woordvoerders Van Herwerden en Co.”, die van de uitvoering dier ,heillooze spoorwegplannen” niet alleen vernietiging hadden geducht door ontzettende bandjirs en aardbevingen, terwijl het transport van goederen en personen de kosten en rentegarantie wel niet zouden goedmaken, maar ook een dusdanige toeneming der openbare onveiligheid hadden verwacht - er werd omstreeks 1870 veel geklaagd over ketjoe-partijen enz. — dat ,men wel zou doen op de Indische begrooting tengevolge van het spoorwegontwerp, jaarlijks eenige millioenen meer voor het bouwen van bentings en voor uitbreiding van de krijgsmacht uit te trekken". Maar die onheilsprofetiën waren niet uitgekomen, en sedert had de Agrarische Wet den groothandel en het bankwezen met blijden moed vervuld: de weg naar Java's binnenland lag open, naar de desa, waar suiker en tabak het bedrijf in de vlakte zou verlevendigen, naar de bosschen van het bergland, waarvan de stammen wachtten om geveld te worden tot het aanleggen van paradijsachtige koffie-landen. De nederige desaman behoefde nochtans niet voor het bezit van zijn grond te vreezen, want dit kwam onder de bescherming van het recht 
en de wet; opgevoerd zou worden de productiviteit van den bodem, nu met de vermindering der heerendiensten een aanvang was gemaakt door de afschaffing van die aan de hoofden, en de conversie van het achterlijk communaal bezit zou van den Javaanschen landbouwer eene persoonlijkheid maken. De strijd tusschen cultuurstelsel en vrijen arbeid was beslist, de nieuwe tijd eischte hervormingen, en tot bepaling van den nieuwen koers stelde de landvoogd zich in verbinding o.a. met A. J. W. van Delden, dien hij van vroeger kende; diens nota verscheen, omgewerkt, in druk na het onverwacht vrijwillig vertrek van Loudon onder den titel van „Blik op het Indisch Staatsbestuur" (1875).

Opbouwende critiek uit het eigen land was hier aan het woord. Spoorwegen, een modern middel van vervoer, mochten aan Java niet langer worden onthouden; al veel te lang was de aanleg daarvan vertraagd door eindelooze debatten, en aangewezen was dan een aanleg, niet zooals tot dusver, door een particuliere maatschappij, weike door het Gouvernement met voorschotten uit den nood moest worden geholpen, doch door den staat zelf, met eigen geld. Evenwel, wijl maar al te vaak openbare werken door het betrokken landsdepartement waren afgeleverd geenszins vrij van gebreken, niettegenstaande het geld niet was gespaard, daar klonk de raad: „De Regeering neme het benoodigd personeel op dezelfde voorwaarden aan als een partikulier doet. Het groot beheer der spoorwegen sta op zichzelf, dus zeer bepaald buiten het bouwdepartement. De Regeering kieze een hekwaam, zelfstandig hoofd, dat niet bemoeilijkt moet worden door onze kleingeestige administratieve vormen en voorschriften. Het (was) bekend, dat er bij de militaire genie in het algemeen goed gewerkt (werd) en dat de kontrôle over het ondergeschikt personeel, waar zooveel op (aankwam), scherp (was) als een gevolg van militaire tucht. Dit laatste voornamclijk ontbrak bij het burgerlijk bouwdepartement, waar de mindere beambten veelal aan zichzelven overgelaten, dikwijls eigenmachtig werk(t)en en handel(d)en ...". Niet onduiclelijk werd hier gedoeld op den oud chef van de Genie in Indië D. Maarschalk, die na zijne pensionneering was overgegaan bij de Ned. Ind. Spoorwegmaatschappij.

Deze had de lijn Batavia-Buitenzorg en die van Samarang naar de Vorstenlanden voltooid, was daarna weder bij den dienst der staatsspoorwegen overgegaan en vervulde bij de organisatie van den dienst een gewichtige rol. Onder dezen grooten organisator zou IJzerman eerlang komen te dienen. 
III.

In 1869 had de Hoofdingenieur bij het Mijnwezen W. H. de Greve tijdens de door hem uitgelokte mijnbouwkundige enz. opneming van Sumatra's Westkust langs den oever van de Ombilin het kolenveld bij Sawah-loento ontdekt en gewerkt aan een plan voor een transportstelsel voor de Padlangsche Bovenlanden met het doel ook om den afvoer dier kolen zoowel naar de west- als de oostkust mogelijk te maken. Bij eene verkenning langs de Kwantan-rivier was deze bij de gevaarlijke stroomversnellingen den 22sten Augustus jammerlijk om het leven gekomen : „,meermalen - zou IJzerman later schrijven bij zijn bezoek aan Doerian Gedang - bezochten wij den kalen heuvel, waarop onder een blauwe zerk door een atappen dak beschut en door een tjoebadak-boom overschaduwd het overschot rust van den mijningenieur De Greve”. En hij herinnerde er aan, dat het onder den invloed van De Greve's ontdekking is geweest, dat de Minister van Koloniën Mr. P. P. van Bosse in 1871 toonde van oordeel te zijn, dat aan het tijdperk van stelselmatige onthouding van Hollandsche bestuursinmenging tegenover de vijandig afwerende, onafhankelijke landschappen van Midden-Sumatra een einde moest komen: ,,de natuur, de minerale rijkdom van den grond (kwam Holland) te hulp bij de uitvoering van maatregelen, die in het belang van ons gezag werden vereischt, of liever (was) een nieuwe aansporing tot het nemen van zulke maatregelen".

In 1873 ving Cluysenaer zijn werk op Sumatra's Westkust aan. Er waren tegenvallers door ziekte; verouderd bleek de topografische opneming van vroeger, toch kon hij in 1875 de uitkomst samenvatten : wilde men de riike kolenlagen langs de Ombilin aan de markt brengen en deze gebruiken als hefboom tot de ontwikkeling van de welvaart der Padangsche Bovenlanden, dan was aangewezen van Landswege aldaar den spoorweg aan te leggen en te exploiteeren, zoomede ,,wenschelijk" om, tot vermeerdering van de in den aanvang geringe inkomsten, de mijnontginning niet aan een concessionaris in handen te geven, doch van Regeeringswege te doen geschieden. Hooge rente zou de onderneming aan de schatkist niet afwerpen, maar evenmin belangrijke opoffering worden vereischt. Ten opzichte van de quaestie : afvoer der kolen naar de oostkust, was bij de oplossing daarvan geen haast, wijl het in de eerste plaats aankwam op den bouw van een spoorweg naar Padang en de baai, welke later de Koninginnebaai is genoemd. 
Naar gelang de opneming ter westkust van Sumatra haar einde naderde, werd het personeel, voor zoover het werd aangehouden, overgeplaatst naar Java. Daar toch was thans de aanleg van Landswege aangevat. Ten leste was de Minister van Koloniën Fransen van de Putte overtuigd, dat inderdaad voor Indië, althans de aanleg van hoofdspoorwegen, zooals door zijn voorganger Mr. P. P. van Bosse voorgestaan was, van Staatswege behoorde te worden uitgevoerd; de voorwaarden dreigden anders te bezwarend voor den Lande uit te vallen. Bij de wet van 6 April 1875 St. No. 61 werd op de begrooting voor het dienstjaar 1875 één millioen uitgetrokken, beschikbaar gesteld uit de batige sloten van vroegere dienstjaren. Onmiddellijk werd aangevangen met den bouw van de spoorlijn Soerabaja-Pasoeroean met den zijtak Bangil-Malang, het begin van de Oosterlijnen, en voortvarend werd hier gewerkt onder de bevelen van den door het Gouvernement weder overgenomen Maarschalk. Bij dit werk vond IJzerman een plaats als Adjunct-Ingenieur.

In het midden van 1878 werd hij overgeplaatst naar Buitenzorg. Het gold daar den aanleg van de lijn Buitenzorg-Bandoeng-Tjitjalengka. IJzerman was benoemd tot sectie-ingenieur, zijn naam heeft hij vooral daar gemaakt.

\section{IV.}

Van 1878 tot 1884 , het jaar, waarin het baanvak tot Bandoeng geopend werd, woonde IJzerman te Buitenzorg. Sedert 1870 was dit plaatsje al definitief de residentie van den Gouverneur-Generaal van Nederlandsch-Indië; wel was toen het grootste gedeelte van de Algemeene Secretarie nog te Batavia werkzaam, doch te Buitenzorg leefde men in ambtelijke sfeer nog min of meer mede met al wat in Indië voorviel, men kreeg een algemeenen kijk op Indische menschen en dingen.

Van Busken Huet is uit het jaar 1873 de volgende boutade. „Een groot aantal personen - schreef hij — kunnen Buitenzorg niet uitstaan. De omfloerste toppen der bergen, zeggen zij, drukken u op de borst als molensteenen, in grijze dekens gewikkeld. Het regent er dag aan dag, telegraafdraden dik. Lange avonden, schaarsche toespraak, de blijmoedigheid afwezig. Wat de natuur betreft: al het onaangename, veroorzaakt door de nabijheid van twee kraters die elkander met donderslagen en bliksemschichten te woord staan. Wat de samenleving aangaat: een geldersch dorp, gebouwd om eene buiten- 
plaats, waar een ongenaakbaar persoon de geheele wereld op een afstand houdt".

In hetgeen op deze zinsneden volgt, komt de andere Busken Huet te voorschijn, die in deze dubbel-natuur school; Buitenzorg straalt dan in het vriendelijk licht van een frisschen, zonnigen morgen in 's Lands Plantentuin, een natuurtafereel eenig in Indië, en wellicht daarbuiten. Hoe het Buitenzorgsche leven was in den kleinen kring. die op het Paleis verscheen, er aan diner's aanzat en in de balzaal zich bewoog; het leven voorts in den huiselijken kring onder luidruchtige, half buiten opgroeiende kinderen, met vrienden, kennissen en buren van korter of langer tijd, uit allerlei rangen en standen, aangewezen als men er vaak was op wederkeerige hulpvaardigheid en vriendelijke belangstelling, - - men kan het voor IJzerman's tijd zien door de oogen van zijn eerste vrouw - pseudoniem Annie Foore in de verschillende schetsjes, welke tusschen 1882-1890 in Eigen Haard van haar hand verschenen. Huiselijke novellen, gevloeid uit de pen van eene gelukkig getrouwde Hollandsche vrouw in een Nederlandsch-Indisch milieu, een opgeruimde natuur met humor, een hartelijke echtgenoote en moeder, eene, die, zooals IJzerman het uitdrukte, ,alles goed deed” en ,alles kon”. In Bogoriana, haar laatste boek, hoort men een nagalm van het neerleggen der landvoogdij ten gevolge van politieke verschillen door den Gouverneur-Generaal 's Jacob, echter in een wereld van verdichting en romantische figuren. Over verschillende tooneeltjes ligt nochtans de kleur van tijd en plaats, en oudere tijdgenooten herkenden trekjes naar het leven.

In 1881 werd IJzerman hoofdingenieur. Het hoofd van den dienst was de Inspecteur-Generaal - tot 1880 was dit Maarschalk, daarna Dercx -, en immer is IJzerman bijgebleven het voorrecht van de buitengewoon zelfstandige positie, welke Maarschalk voor dat ambt had weten te verwerven; den met de uitvoering ter plaatse belasten persoon moest men de verantwoordelijkheid laten. De aanleg schoot hard op. IJzerman was een geducht chef; ongezouten kon hij zijn oordeel uitspreken, maar aan den anderen kant lag goedkeuring in den eenvoud van het aanbieden van den geopenden sigarenkoker met de woorden :,steek maar eens op". Van zijn personeel kon IJzerman zooveel gedaan krijgen, omdat hij zichzelf niet spaarde, zelf voorging. Zwakke krachten kon hij niet gebruiken, dezen gunde hij den tijd om elders een kans te krijgen. Hij begon al geraadpleegd te worden ook voor quaesties, welke niet direct op zijn dienst betrekking hadden; zoo o.a. werd hij helast met een onderzoek naar het wegenstelsel in 
de residentie Preanger-regentschappen, waardoor de aanleg ging, .-een opdracht, waarbij aan het licht kwam dat op verschillende punter: de topografische kaart niet deugde.

Hoezeer zijn kennis en toewijding op prijs werd gesteld, bewees eene hem in 1884 voor buitengewone en goede diensten toegekende gratificatie. In dat jaar eindigde zijn Buitenzorgsche tijd.

\section{V.}

Zijn standplaats werd Djokjakarta. Van twee zijden zou daar de spoorverbinding worden aangevat. In het westen te Tjilatjap, de doodstille haven achter het „drijvend eiland" Noesa Kambangan, welke destijds met alle geweld moest worden verbonden, - om strategische redenen, zoodat aan dat project de voorkeur was gegeven boven den bouw van een stamlijn der staatsspoorwegen langs Java's noordkust. In het oosten ging de aanleg van Djokja uit; dáár was het aanhechtingspunt met de Ned. Ind. Spoorwegmaatschappij Samarang-Vorstenlanden, welke het verschiet opende op een doortrekken van de Westerlijnen naar de Oosterlijnen, de verbinding van Batavia met Soerabaja. Aanvankelijk was het plan om de baan door Bagelen over Poerworedjo te leggen en dit te verbinden met Magelang, terwijl de opneming Djokja-Magelang-Willem I reeds voltooid was. Tot uitvoering van dat plan is het niet gekomen. Van de twee belangrijke wijzigingen was de eene, dat op de grens van Banjoemas bij Idjo een tunnel zou worden geboord, hetgeen eene verkorting der baan gaf, welke bij de exploitatie van blijvende waarde zou zijn, een verbetering, welke IJzerman met welgevallen is blijven herdenken; de tweede was, dat de baan over Koeto-ardjo doorgetrokken werd. Poerworedjo liet men liggen, het zou later van Koeto-ardjo uit worden aangesloten, en van de verbinding met Magelang kwam evenmin iets. Wanneer wij bedenken, dat het stuk PoerworedjoMagelang zou aansluiten op eene verbinding Willem I-MagelangDjokjakarta en het tracé daarvan liep over den Tjandi Mendoet, dan zien wij IJzerman's dienstreizen hem meermalen voeren langs de Boroboedoer, waar hij ,,alsdan zelden verzuimde eenigen tijd bij dit merkwaardigste bouwwerk van Java te vertoeven".

Omgeven door grootsche bouwvallen uit een geheimzinnig verleden, voelde IJzerman te Djokja zijn weetlust ontwaken. In de rijke bibliotheek van den landhuurder C. M. Baumgarten viel hem, naast werken over Britsch-Indische archaeologie, in handen Hodgson's toen zelfs 
aan Groeneveldt nog onbekende „Essays on the languages etc. of Nepal and Tibet". Een ondergegane religieuze bouwkunst herleefde. Op Java, waar de hevige koffie- en suikercrisis van 1884 woedde, was de tijd er niet naar om een oudheidkundig onderzoek te bekostigen; planters, credietinstellingen, en het Gouvernement maakten allen zorgelijke tijden door. Maar met naast zich den enthousiasten Dr. I. Groneman, lijfarts van den Kraton, wist IJzerman Resident en Sultan benevens verschillende landhuurders voor zich te winnen en met dezer schenkingen en bijdragen de Djokjasche oudheidkundige vereeniging op te richten, waarvan hij de bezielende voorzitter werd.

\section{VI.}

Op de October-vergadering 1885 van de Directie van het Bataviaasch Genootschap van Kunsten en Wetenschappen kwam een brief in, ged. Jogjakarta 16 Sept., waarbij IJzerman mededeelde, dat de onlangs aldaar opgerichte vereeniging, welke zich ten doel stelde gegevens te verzamelen, belangrijk voor de studie van de oudheidkunde, geschiedenis en de land- en volkenkunde der Vorstenlanden, haar werkzaamheden had aangevangen met den hoofdtempel van Loro Djonggrang in het Prambanan-complex. Uit het middenvertrek was een massa van ongeveer $500 \mathrm{M}^{3}$ zware steenen naar buiten gebracht; aan het licht was gekomen in het bijzonder een Siwa-beeld, vierarmig, staande met zijn lotoskussen op een fraai bewerkte yoni; een beeld van $3 \mathrm{M}$. hoogte, zwaar heschadigd, en daarvóór een diepe put, welke nog niet ontgraven was. Dat was het eerste teeken van leven dat de jonge vereeniging aan Batavia gaf, een zeer belangrijk bericht.

Een tweede brief was die, waarbij de Directeur van O. E. en N. om raad verzocht in zake de missive van den Resident van Djokjakarta, waarin de vergunning van de Regeering verzocht werd voor de jonge vereeniging om hare onderzoekingen en ontgravingen „op eenigszins uitgebreide schaal voort te zetten". Het Directie-lid, de Heer W. P. Groeneveldt, wiens naam gevestigd was door de in 1877 verschenen Notes on the Malay Archipelago en die het conservatorschap voor de oudheden in het Museum van het Bataviaasch Genootschap op zich had genomen - twee jaar later verscheen zijn vermaarde beschrijvende catalogus, - was van een en ander reeds op de hoogte, en niet in de laatste plaats zal hij medegewerkt hebben om te adviseeren de gevraagde vergunning te verleenen en de hoop tot samenwerking uit te spreken, alsmede de publicatie der resultaten 
van de Djokjasche vereeniging in de werken van het genootschap aan te bieden en in overweging te geven de in Djokjakartasche particuliere verzamelingen voorkomende beelden, beschreven steenen enz. ter hoofdplaats samen te brengen. Daarmede was de band gelegd tusschen Djokja en Batavia.

Opnieuw werd Mataram ontdekt, het Hindoe-Javaansche. In de trotsche bouwvallen van Prambanan - reusachtige steenhoopen was het opruimingswerk reeds begonnen. Tjandi Kalasan kwam aan de beurt, waar de versiering van het zuiderfront op het invallen scheen te staan; van het interessantste gedeelte van den geheelen bouwval, het dak, gelukte het met moeite - IJzerman waagde den levensgevaarlijken klim - nauwkeurige bouwkundige opmetingen te doen en eene teekening te vervaardigen. Men bereikte de plek, waar volgens de legende de kraton van Ratoe Baka had gestaan: ,eenzaam en verlaten - schreef IJzerman - is het thans hier, waar vroeger zooveel leven en beweging heerschte; hier, waar machtige vorsten, tegen iederen vijandelijken aanval door de natuur beveiligd, met verachting konden nederzien op hunne onderdanen, die in de vlakten noord- en zuidwaarts op hun bevel trotsche tempelgebouwen deden verrijzen, naar zij meenden, onvergankelijke getuigen van hun roem en grootheid".

Dit ontdekkingswerk werd verricht voor zoover de dienstwerkzaamheden dit toelieten, en, wat de leiders betreft, belangeloos. Op den voet gevolgd door opmeter en teekenaar - want met het BritschIndisch voorbeeld voor oogen zou een bepaalde werkwijze worden gevolgd en het gevondene wetenschappelijk worden vastgelegd wijdde IJzerman met den Ingenieur Hubenet, dien hij had gewonnen, zich aan de opsporing en inventarisatie en zorgde voor eene opzending naar Batavia v. z. v. nader deskundig onderzoek vereischt bleek. IJzerman behield zich voor de bouwkundige beschrijving, Groneman nam op zich de over verschillende plaatsen verspreide beelden onder te brengen in een soort museum en daarvan een catalogus samen te stellen. Hij zou later IJzerman als voorzitter opvolgen.

Bewondering wekt, dat in de spanne van slechts één jaar met geringe geldelijke hulpmiddelen zóó sprekende uitkomsten zijn verkregen. Toegegeven moet worden, dat de aanwezigheid en samenwerking van een drietal toegewijde deskundigen op Java dit resultaat mogelijk heeft gemaakt. In het Bataviaasch Genootschap, dat bij zijn tot de Regeering gericht vertoog van 1885 had gevoegd de BritschIndische nota over de ,reorganisation of the archaeological depart- 
ment", was Groeneveldt ondervoorzitter en Brandes directielid, maar IJzerman deed de electrische vonk overspringen, en waar de Regeering, die geenszins onverschillig was doch in de crisis-periode van 1884 tot 1888 zich heel veel moest ontzeggen, het geld niet kon verstrekken, was te verdienstelijker de particuliere steun, en IJzerman had het talent, de gave daartoe op te wekken, - toen en later.

In Mei 1886 vertrok IJzerman met verlof naar Holland. Hier stelde hij, na te Batavia overleg gepleegd te hebben met Groeneveldt, en te Leiden de medewerking van Leemans, Kern en Pleyte te hebben verkregen zijne ,Beschrijving der Oudheden nabij de grens der residenties Soerakarta en Djogjakarta" op, welke vervolgens door het Bataviaasch Genootschap in 1891 werd uitgegeven, - tot besparing van kosten op Java gedrukt, er was destijds nog altijd geen ruimte van middelen. ,Niemand — schreef IJzerman in het Voorwoord - is meer doordrongen van het feit, dat hij hier een terrein betreedt, waarop hij geheel vreemdeling is, dan de schrijver. De gedachte echter, dat opperlieden even noodig zijn als architecten, om een gebouw op te richten, deed mij er toe besluiten. Velen waren mij bij dezen arbeid behulpzaam; alle leden der Djogdjasche Vereeniging met den beschermheer, den Resident Van Baak aan het hoofd, hebben hun medewerking verleend, in het bijzonder de Heeren Hubenet en Leydie Melville. Met de meeste belangstelling werden onze werkzaamheden gevolgd en dikwijls geleid door den Heer W. P. Groeneveldt; ook Dr. Brandes ontstak meermalen licht, waar wij in duisternis rondtastten" enz.

Met dit werk vestigde IJzerman zijn naam op het gebied van Java's oudheidkunde; nog wordt het door Prof. Krom „,een standaardwerk” genoemd, dat ,ook thans, na bijna dertig jaar, waarin zooveel aan onze kennis van de Hindoe-Javaansche kunst is toegevoegd, aan iedere beschrijving van de oudheden van Prambanan ten grondslag kan blijven liggen".

Na IJzerman's vertrek werd het werk voortgezet. Hierbij vinden wij den naam van een enthousiasten medewerker op het gebied van Java's, van Indië's oudheidkunde en geschiedenis, die later met IJzerman zou samenwerken. IJzerman's dienstreizen - zagen wij hadden hem vaak gebracht voor de Boroboedoer. Zijn oog werd daarbij getroffen door een bouwkundige afwijking, en intuitief tot de overtuiging gekomen, dat daarvoor een verklaring zou zijn te vinden bij een onderzoek naar den ouden voet van dit wonderwerk, had IJzerman, daartoe door Groeneveldt angemoedigd, met ver- 
gunning van den Resident van Kedoe, een gedeelte daarvan bloot gelegd. Niet alleen was hem toen gebleken, dat het basement van de Boroboedoer denzelfden vorm had als dat van de Tjandi Mendoet, maar ook waren daarbij twee bas-reliëfs aan het licht gekomen, welke voorzien waren van korte inscripties. Deze werden door Brandes gelezen, maar tot eene verklaring had het toen nog niet kunnen komen. In een sober artikel „Iets over den oorspronkelijken voet van Boro Boedoer" in het tijdschrift van het Bataviaasch Genootschap gaf IJzerman verslag van zijne ontdekking. ,Mocht - schreef hij aan het einde daarvan - (tot een onderzoek naar den geheelen voet) worden besloten, dan zullen honderde opschriften van den tot heden zwijgenden tempel spreken, en een nieuwe reeks schoone basreliëfs zal daaraan nieuw belang bijzetten. Dan zal het oogenblik gekomen zijn tot het schrijven van het tweede deel van Dr. Leeman's welbekend Boroboedoer".

In de vergadering der Directie van het Batav. Gen. voor K. en W. van 5 Oct. 1886 deed Brandes - deze was in eind 1884 op Java aangekomen - mededeeling van de afdrukken van legenden, gevonden bij de basreliëfs, welke ter weerszijde van de door den Heer IJzerman aan het licht gebrachte reliëfs, aan den voet van de Boroboedoer waren blootgelegd door den Heer.... G. P. Rouffaer. In een brief van 27 Oct. 1887 was Rouffaer zelf an het woord, men vindt hem in den stijl aanstonds terug.

Boroboedoer's voet werd sedert bij gedeelten blootgelegd en gephotographeerd, welke arbeid in 1891 voltooid was. De verklaring van de reliëfs heeft intusschen nog lang op zich laten wachten. Zelfs toen twintig jaar later het geheele wonderwerk door deskundige hand was opgenomen overeenkomstig de eischen van de moderne archaeologie, was men daarmede nog niet verder, alleen was voor tafereelen in den bovenbouw al gewezen op de Jataka-mala en de Lalita-wistara. Eerst nog twintig jaar later verscheen de bouwkundige beschrijving, op welke IJzerman was blijven wachten, en juist toen was men toe gekomen aan de verklaring der reliëfs van den weder toegedekten voet.

Op het 6de Congres van het Oostersch Genootschap te Leiden deelde Sylvain Lévi mede, dat de reliëfs daarvan verklaring vonden in een Boeddhistischen tekst, de Karma-wibhangga, welke hem in Nepal in handen gekomen was. IJzerman was onder de toehoorders; persoonlijk herdacht werd de ontdekker niet, men is gauw vergeten.

En de bedolven voet? Voortreffelijk zijn de heliografische repro- 
ducties van de door den Heer Cephas genomen fotografiën in het aan IJzerman opgedragen tweede deel van de Boroboedoer-monografie, dat de bouwkundige beschrijving bevat, maar eene teleurstelling is het voor IJzerman geweest, dat van die reliëfs geen afgietsels zijn gemaakt, toen naderhand met betrekking tot de Parijsche Wereldtentoonstelling van 1900 door hem gevoerde onderhandelingen de gelegenheid daartoe schenen te kunnen verzekeren.

Een teleurstelling ook, dat na de voltooiing van de opneming de voet over de volle lengte weder geheel werd toegedekt, zonder althans een gedeelte te laten in zoodanigen toestand, dat de bezoeker zich met eigen oogen eene vourstelling kan maken van het wonderwerk, zooals de vrome bouwheer zich zijne schepping had gedacht.

\section{VII.}

„Ze liggen daar goed”, moet van de Ombilin-steenkolen gezegd zijn door een Nederlandsch staatsman, die het met Cluysenaer's advies: in de Padangsche Bovenlanden spoorweg- en steenkolenbedrijf van staatswege, niet eens was. Men heeft zich inderdaad niet gehaast met eene beslissing te dien aanzien. Voor Java duurde het eerst al een heele tijd, vóór men tot spoorweg-aanleg van staatswege overging, en toen het zoover was, werd een oogenblik nog geopperd om althans de exploitatie aan particulieren te gunnen. Ten opzichte van Sumatra's Westkust kwam daarbij nog de quaestie hoe te handelen met de steenkolen-ontginning.

Belangrijke Indische onderwerpen maakten destijds vaak het onderwerp uit van langdurige overwegingen op het ministerie en niet minder lange gedachtenwisselingen in en buiten het Parlement tusschen specialiteiten en anderen, terwijl in Indië de Europeesche kolonie met wrevel en stijgend ongeduld toezag, hoe in de verte over Indië beslist werd door moederlandsche en partij-politiek met de beschikking over door Indië ruimschoots en alleen opgebrachte gelden. Maar eindelijk moest toch wel eene beslissing worden genomen over de welvaartspolitiek op Sumatra's Westkust; magna est veritas et praevalebit, de Minister Sprenger van Eyk diende het wetsontwerp in, waarvan IJzerman de Memorie van Toelichting had opgesteld, en ,,met bijna voorbeeldeloozen spoed” werd dit in beide kamers der Staten-Generaal aangenomen, waarna bij de Wet van 6 Juli 1887 de aanleg van den spoorweg Emmahaven-Padang-Padang pandjang- 
Sawah loento met een zijtak Padang pandjang-Fort de Kock werd gelast.

IJzerman werd te Padang de chef van den dienst. Interessant was het werk door de vele en groote terreinmoeilijkheden : de baan volgde den grooten weg door de Anei-kloof met scherpe bochten en steile hellingen, welke het toepassen van tandrad-staven vereischten - de eersten in Indië - en hechte steunmuren moesten zware bandjirs afweren. In den nacht van den 23sten op den 24sten December 1892, anderhalf jaar na de opening van het baanvak, zou een stortvloed van ongekenden omvang eene verwoesting aanrichten, welke maandenlang het goederenvervoer zou stremmen en meer dan een half millioen aan herstelkosten zou veroorzaken.

Voortvarend was IJzerman als altijd. Toch vond hij nog den tijd - na herhaalde aansporing van Groeneveldt te Batavia - om aan de Kampar-kanan den eenzamen torentempel in de verlaten kota te Moewara Takoes op te nemen, af te teekenen en te onderzoeken. Deze had bij herhaling reeds de belangstelling gewekt; hij bleek een Boeddhistische stoepa met daarnevens een dagob en terrassen te zijn. Nauwkeurig werd de ruïne opgenomen en beschreven - IJzerman werd bijgestaan door den Ingenieur Th. A. F. Delprat, met wien hij steeds nauw in relatie is gebleven - en den opzichter Leydie Melville, die hem reeds te Djokjakarta van veel dienst was geweest en later aan den oudheidkundigen dienst zou worden verbonden.

Het gouvernement van Sumatra's Westkust genoot belangstelling. De Padangsche Bovenlanden behoorden tot de mooiste berglanden ter wereld door de woeste pracht van het oerwoud, waaruit de grijs getinte toppen der vulkanen oprezen, en ,zoowel de Boven- als de Benedenlanden werden geacht te behooren tot de welvarendste provinciën van ons Indisch rijk". Maar Padang, centrum van den handel ter kuste, was niet overdruk. Zouden echter de Menangkabouwsche wereld met haar schilderachtige dorpen, bevloeide sawahs en schoone koffietuinen, alsmede de vruchtbare landen in het Barisan-gebergte en de rijke kolenvelden van Sawah Loento met de nieuwe haven in de veilige Emmahaven zijn verbonden door een ijzeren weg, die het verkeer zou verzekeren, dan zouden ,landbouw, handel en nijverheid n:euw leven ontvangen en tot een ongekende ontwikkeling geraken", Padang zou herrijzen. Reeds had het Gouvernement al meer behoefte aan goeden steenkolen voor zijn eigen spoorwegen op Java en de Kon. Marine. De groote Nederlandsche stoomvaartmaatschappijen deden Padang aan, en wanneer het dan gelukken mocht om aan gene zijde 
van het Barisan-gebergte dwars door het woud en langs een der trotsche rivieren van Midden Sumatra een afvoerweg te vinden, waarvan de kosten financiëel verdedigbaar zouden zijn, om de Ombilinsteenkolen te Singapore op de markt te brengen, - welk een verschiet opende zich dan niet! Voortvarende landbouwondernemers zouden niet aarzelen hun kapitaal in den grond te steken, en dan: de politiek van een doorgaanden spoorweg van Padang naar Siak. „De naam van het Gouvernement zou groot worden over Midden Sumatra, en verwikkelingen met de onafhankelijke staatjes, die zich onaantastbaar waanden en daarom zoo dikwerf het Nederlandsch gezag durfden honen, zouden tot de geschiedenis behooren". Na zorgvuldige onderzoekingen van mogelijkheden en plaatselijke toestanden over de grens van ons toenmalig grondgebied, maakte IJzerman in Mei 1890 aanhangig hem toe te staan om, wanneer de politieke verhoudingen met de Kwantan-districten zich daartegen niet verzetten, eene globale verkenning te verrichten tot Siak, en, indien de uitkomsten daarvan gunstig zouden zijn, over te gaan tot opnemingen ten behoeve van het voorontwerp van een spoorweg.

Den 22sten April 1891 hield IJzerman te Batavia in de zaal van den Planten- en Dierentuin, daartoe uitgenoodigd door het Bestuur der Kon. Natuurk. Vereeniging in Ned. Indië, des avonds zijne voordracht over den tocht dwars door Sumatra; klaar en zelfbeheerscht droeg hij zijn reisverhaal voor, zeker van zich en van zijn publiek; welverdiend was het succes zoo voor hemzelf als voor den Voorzitter der vereeniging, den Directeur B. O. W. tevens zijn gastheer, M. J. van Bosse, die van meet af zijn streven had bevorderd en wiens gelukwensch de eerste was geweest, welke den koenen ontdekker te Singapore bereikte. De zorgvuldige voorbereiding van de expeditie door persoonlijke onderhandelingen op de grens en besprekingen met zendelingen, gevolgd loor bezoeken van Midden-Sumatraansche hoofden; het optrekken der kolonne van 260 man onder het commando van IJzerman, bijgestaan, door den Eersten Luitenant van den topografischen dienst L. A. Bakhuis, Dr. J. F. van Bemmelen, zoöloog, den Houtvester S. H. Koorders enz.; de overval in het bosch bij Logei, waarbij de opzichter Van Raalten verraderlijk werd doodgeschoten en naast IJzerman de Javaansche mandoer Enteng doodelijk gewond; de verkenning, al kappend zich een pad banend door het eindelooze woud, waar onder het eentonige looverdak een dompige dampkring zwaar op de stemming drukte, dagmarschen te midden van een doodsche stilte; vervolgens eenzaam, armelijk heu- 
velland en ten slotte de ontmoeting weder op Gouvernementsgebied met de van de oostkust gezonden helpers, - deze tafereelen trokken het oog voorbij. Men vindt ze terug in het ten jare 1895 verschenen, voortreffelijk geillustreerde werk „Dwars door Sumatra”, dat, opgebouwd uit de dagboeken der deelnemers der expeditie, een nauwkeurig verslag bevat. IJzerman op zijn eerste reis naar Loeboek Ambatjang te midden van zijn Inlandsche metgezellen, een andermaal tijdens den tocht afgebeeld in het kampement bij Soengei Batoeng, zijn foto's, welke ons in de ruwe werkelijkheid verplaatsen. Aller vertrouwen was op dezen onversaagden man gevestigd, die vastberaden doorzette en wiens groote kalmte de verwarring en onzekerheid herstelde toen bij den overval te Logei de onmisbare dragers der kolonne van schrik uiteengestoven waren.

IJzerman eindigde zijn met de grootste belangstelling aangehoorde lezing te Batavia met den wensch: dat spoedig de slagboom, die de westkust van Sumatra scheidde van de oostkust van dat prachtige eiland, mocht worden verbroken door het stoomiros, dat in die ontoegankelijke wouden en onherbergzame streken leven, welvaart en beschaving brengen zoude.

\section{VIII.}

Het heeft niet zoo mogen zijn. IJzerman had reeds opgemerkt, dat, al was het hem een blijde ondervinding geweest, dat in de onafhankelijke streken de aldaar zich bevindende Maleiers, die van de Gouvernementslanden afkomstig waren, zich overal bereid toonden zijne expeditie te helpen, ,,men echter verkeerd zou doen daaruit af te leiden, dat wij ons slechts in de onafhankelijke staatjes hebben te vertoonen, om overal als weldoeners en verlossers te worden ingehaald. Wij doen dit - vervolgde hij - zoo gaarne; en geen wonder, want onze bedoelingen zijn zoo edel. De Nederlandsche natie is immers de draagster van beschaving, ontwikkeling en vooruitgang in den Indischen Archipel. Dat is het, wat velen die niet onder haar vleugelen rust en veiligheid vinden, niet willen begrijpen. De hoofdoorzaak van dien onwil is het verschil in godsdienst, dat een moeilijk te dempen kloof vormt. Het fanatisme werkt rusteloos om haar te verwijden, en vindt een gemakkelijke taak door de lichtgeloovigheid der menigte. Bijna niemand kan hier lezen en schrijven, en wie het geleerd heeft, ging ter schole bij meestal dweepzieke godsdienst- 
leeraars op ons gebied...., ,Zoo zullen dweepzucht en bandeloosheid factoren blijven waarmede bij elke volgende aanraking met de Kwantanstreken rekening moet worden gehouden. Daar bestaat geen macht, die orde en tucht, recht en veiligheid kan handhaven. Zoo ergens, - besloot hij - zou onze ovierheersching daar ten zegen kunnen zijn!" Dat heeft gewacht tot Van Heutsz orde ook in Midden Sumatra op de zaken heeft gesteld, en hoezeer IJzerman dien landvoogd daarvoor heeft gewaardeerd, ligt in het vorenstaande opgesloten.

Wijl het tijdstip naderde, waarop de exploitatie van het kolenveld zou behooren aan te vangen, vertrok IJzerman naar Holland en keerde weder terug, nadat hij het door den Minister Mackay in 1891 ingediend wetsontwerp tot voorbereiding van dat bedrijf had zien aannemen, en hij zelf in Europa een mijningenieur, die onder hem aan het hoofd van de ontginning zou staan, had uitgekozen. IJzerman trad op als hoofdingenieur, chef van èn den spoorweg èn de mijnontginning, en bracht met het oog op die dubbele functie een door hem zelf ontworpen instructie mede, waardoor hij voor het spoorwegbedrijf wel is waar administratief onder den Directeur B. O. W., zoude staan, doch overigens rechtstreeks ondergeschikt alleen aan den Gouverneur-Generaal. Op Java was juist een einde gemaakt aan de groote zelfstandigheid van den Inspecteur-Generaal der Staatsspoorwegen, IJzerman vorderde deze naar het voorbeeld van Maarschalk voor zich op en verkreeg haar. Wanneer gesproken wordt over de met het regime-Maarschalk verkregen ,,voortreffelijke uitkomsten”, dient vooropgesteld, dat die: meestendeels het uitvloeisel zijn geweest van de persoonlijkheid, en hetzelfde geldt voor IJzerman. Diens exceptioneele positie werd gewettigd door de buitengewone omstandigheden: het in elkander grijpen van de twee geheel verschillende, echter beiden op den grondslag van geldelijk voordeel in te richten bedrijven en de aanwezigheid van een spoorwegingenieur, die op Java bewezen had een onwaardeerbare kracht te zijn als voortvarend chef, die met helder inzicht op practische doeleinden zijn energie swist te concentreeren.

„In dien tijd - schreef Prof. Van Eerde uit eigen aanschouwing was IJzerman een soort dictator ter Westkust; de hoogste bestuursambtenaar hield rekening met zijn wenschen, immers de Regeering hoopte op de spoedige voordeelen van de kolenontginning en den kolenafvoer naar de kust; immers was hij de man, die over extratreinen, directierijtuigen, een uitgebreid personeel van Europeanen 
en Inlanders beschikte. In dien tijd was de hoofdingenieur-exploitatiechef degene, die met den aanstaanden landvoogd Jhr. van der Wijck rondreisde en dezen inlichtte over den toestand ter kuste... Tot zijn pensionneering in 1896 was IJzerman in Padang en Fort de Kock en Solok en Sawahloento een geduchte figuur voor wie hem tegenwerkte of slecht diende, een aangename gastheer, voor wien hij noodde, een gerespecteerd chef bij zijn medewerkers, een door de meesten gemakkelijker met achting dan met genegenheid te zien persoon".

Tijdens zijn verblijf in Holland was IJzerman, die in 1890 weduwnaar was geworden, hertrouwd; onder de gelukwenschen was er een van een opzichter, een der stille vromen, met enkel de aanhaling: Numeri VI vs. 24; die heeft IJzerman wel bijzonder getroffen. Hij was een gevoelig man, had hart voor zijn ondergeschikten, die hem trouw dienden, dezen waren op hun beurt erkentelijk. Bewezen diensten vergat hij nooit en vriendschappen hield hij zijn leven lang.

Op Sumatra's Westkust heeft hij hard gewerkt, het oog over alles en allen latende gaan, den spoorweg, de kolenontginning, de behandeling der te Sawahloento werkzame dwangarbeiders, - er waren er over de uizend, onmisbaar werkvolk, waarvan — betoogde hij bij herhaling te Batavia aan het Departement van Justitie - hij er eer te weinig dan te veel had. Met den door hem medegenomen mijningenieur vlotte het niet, het liep uit op een botsing tusschen den aarden en den ijzeren pot. Van het mijnbedrijf heeft IJzerman gemaakt wat er van te maken viel, de aanvoer van buitenlandsche kolen drukte echter den prijs, en de Ombilin- waren nu eenmaal geen Cardiff-kolen. Niet alleen de waardeering genoot hij van den Gouverneur-Generaal Van der Wijck, er was een bijzonder aangename verhouding. De landvoogd bood hem een plaats aan in den Raad van Indië, maar IJzerman had ,nog niet met het leven afgerekend"; in 1896 had hij, die jaren lang in zijne dubbele functie een traktement genoten had, hooger dan een raadslid, recht op het daaraan verbonden pensioen; hij was 45 jaar oud en zag in de verte Amsterdam liggen, nog altijd Holland's eerste handelsstad wat betrof Indische belangen, zetel van nieuwe ondernemingen, een verschiet met allerlei mogelijkheden.

Hij nam afscheid en vertrok in September 1896 naar Holland. 
IX.

In Februari 1897 wilde beweging ter Effectenbeurze in Amsterdam: ter plaatse waar Koninklijke en Moewara Enim werden verhandeld, woelde, krioelde alles dooreen, aandeelen der eerste kelderden, die van Moewara Enim waren speelbal van hartstochtelijke speculatie, koopen, verkoopen. Wat wąs er aan de hand?

Groote petroleumbelangen stonden op het spel. De „Koninklijke”, die in Langkat werkte en langzamerhand den tegenspoed te boven was gekomen, was een machtige organisatie geworden, zoozeer dat als het ware vanzelf nadere aansluiting met haar tot stand kwam. Aan haar was o.a. verbonden de Ned. Ind. Exploratie-maatschappij, die in Palembang op de zoek was naar vindplaatsen: in 1896 had deze aldaar niet minder dan 273 aanvragen. $Z \mathrm{ij}$ vond echter naast en tegenover zich de Moewara Enim-maatschappij - een belangengemeenschap van Amsterdamsche bankiers enz. - welke haar arbeidsveld had in Lematang-ilir; zij zelf werkte in Iliran en Banjoe-asin.

De Moewara Enim had haar aandeelhouders opgeroepen tot eene vergadering ter oprichting, in samenwerking met de Standard Oil Cy te New-York, van eene nieuwe Nederlandsche maatschappij, te vestigen te Amsterdam, in het kapitaal waarvan beide partijen zouden deelnemen; de Moewara Enim zou zich voortaan bepalen tot het trekken der baten. Partijen zouden overeenkomen hunne aandeelen gedurende 20 jaren niet aan derden te verkoopen, echter zou de Standard Oil Cy het recht verkrijgen gedurende 5 jaren om de aandeelen der Moewara Enim in de nieuwe maatschappij ,en bloc" over te nemen à $300 \%$. Als directeur der nieuwe maatschappij zou optreden die van de Moewara Enim, de Heer IJzerman.

Het motief voor deze politiek was te zoeken in de organisatie van den afzet van het gewonnen product. De Moewara Enim beschikte over genoeg kapitaal om de olie te voorschijn te brengen en eene raffinaderij daarvoor te Pladjoe in bedrijf te brengen, doch stond voor de moeilijkheid van de verscheping en de oprichting van tanks in het buitenland alsmede den verkoop aldaar. In den belangenstrijd met de Koninklijke had IJzerman aangedurfd een eigen weg te gaan, toen hij zeker was steun te kunnen vinden bij de Amerikaansche maatschappij. Was Ned. Indië niet het land van de ,open-door”politiek? Hoe groot was niet het antal ondernemingen op Sumatra's Oostkust enz., wier zetel in Nederland of Nederlandsch-Indië was 
gevestigd, doch werkten met geheel of gedeeltelijk buitenlandsch kapitaal? Echter het was niet alleen de belangen-oppositie, welke over het plan van de Moewara Enim-maatschappij niet gerust was: het gevolg van een samengaan met een zoo geweldig sterke Amerikaansche trust als de Standard Oil zou allicht zijn, dat de nieuwe maatschappij, in naam Nederlandsch echter in verband met de kapitaalverhouding voor ${ }^{2 / 3}$ Amerikaansch, zou blijken te zijn een der vele ondernemingen van het groote concern, en de Standard Oil in staat zou stellen zulk een overmachtige positie in te nemen, dat de snelle ontwikkeling van een eigen mijnbouw in de kolonie zou worden geschaad, gestuit. Een brief van den Minister Cremer trok een scherpe grens: de Moewara Enim Maatschappij werd gewaarschuwd, dat, indien het plan voortgang had, de verleende vergunning voor mijnbouwkundige opsporing welke niet voor overdracht vatbaar was, niet zou worden omgezet in eene concessie tot winning van het product.

De strijdende partijen zijn ten slotte tot een vergelijk gekomen : in 1904 droeg de Moewara Enim de exploitatie harer terreinen over aan ,de Koninklijke”, waarbij IJzerman als commissaris optrad. In den Raad van beheer verwierf hij langzamerhand een leidende positie, meermalen was hij het die strijdige belangen wist te verzoenen. Werd van koopmanszijde op den voorgrond gebracht, dat het de handel was, die de groote winsten deed behalen, IJzerman stelde daartegenover, dat de koopman afhankelijk was van hetgeen de ingenieur te zijner beschikking stelde.

Vrouwe Fortuin had ook hier aan de zijde van den stoutmoedige gestaan, de overwinning was behaald; wat nu?

$\mathrm{X}$.

In IJzerman is altijd de ontdekker wakker gebleven. Ook in Amsterdam, centrum van handel, wetenschap en kunst, dat in 1897 al duidelijker een tijd van voorspoed zag aanlichten. Hij had in 1892 in den kring van het Koninklijk Aardrijkskundig Genootschap, dat onder zijne leden telde velen in stad en land, die belang stelden in vreemde landen en onze koloniën, niet alleen uit een koopmansoogpunt, zijn tocht „dwars door Sumatra” voorgedragen. Lid van die vereeniging was hij van het tijdstip der oprichting af in 1873, in 1897 werd hij in het bestuur daarvan gekozen, te zamen met Groe- 
neveldt, die het vice-presidiaat van de Raad van Indië had nedergelegd, de studie weder had aangevat en thans als voorzitter van het genootschap optrad. J. T. Cremer, welhaast Minister in het kabinet-Pierson - beiden Amsterdammers -, had de benoeming aanvaard van Commissaris-Generaal voor Nederland bij de Parijsche Wereldtentoonstelling van 1900; in de groep XVII „Colonisation” nam IJzerman, oud hoofdingenieur, chef van den dienst der staatsspoorwegen op Sumatra, het voorzitterschap op zich, ondervoorzitter tevens secretaris was G. B. Hooyer, oud overste van het Ned. Ind. Leger.

Beiden waren het er over eens, dat de Indische afdeeling van Nederland moest worden gehuisvest in Indische gebouwen en een beeld moest geven van de schoone bouwkunst van vroeger zoowel als van de schilderachtige woningen van het heden: eerlang verrees op het terrein van het Trocadero eene reconstructie - met behulp van Tjandi Plaosan-gegevens vervolledigd — van de Tjandi Sari bij Prambanan met daarvoor gelegen terrassen, in de opstaande wanden waarvan afgietsels waren aangebracht van bas-reliëfs van de Boroboedoer. Op den achtergrond staken Menangkabausche adat-woningen ,geestig af" tegen den grijsgelen Javaanschen kloostertempel en het groen van de omgeving. Dat had eenige jaren voorbereiding, studie en kunstvaardigen arbeid ook in de kolonie vereischt - de directeur van de school van Kunstnijverheid te Haarlem Von Saher was voor de afgietsels en de reconstructie naar Java gereisd - , en dat dit mogelijk was gemaakt, was te danken aan de vrijgevigheid van Cremer, die uit eigen middelen een som van f 25.000 beschikbaar had gesteld om te Parijs den vreemdeling een goed beeld van Java's oude kunst te geven. De reliëfs van de Boroboedoer waren uitgezocht in overleg met Groeneveldt. Eenstemmig was de lof, en Cremer was zoo voor de zaak gewonnen, dat hij als Minister van Koloniën een post voor de archaeologische opneming van Java op de Indische begrooting van 1901 bracht. Zijn opvolger Van Asch van Wyck verhoogde dien post en daarmede was de voortzetting van de juist begonnen opneming verzekerd.

Dit viel samen met de bemoeienis op Java van het Bataviaasch Genootschap, dat voortdurend had geijverd voor het behoud der oudheidkundige monumenten en inzonderheid gewezen had op het dreigend gevaar voor de Boroboedoer. Reeds was de herstelling van Tjandi Mendoet in uitvoering, het fraaie tempeltje Tjandi Pawon, dat door een reusachtigen wilden randoe-boom uiteen gerukt werd, 
zou worden gered en terzijde werd gelegd het „fantastisch” idee om de Boroboedoer te overkappen. De Boroboedoer-Commissie werd na volbrachte taak ontbonden, en in 1901 op Java de Commissie voor het oudheidkundig onderzoek op Java en Madoera ingesteld, met Brandes als voorzitter. „Aan IJzerman komt de eer toe eerst te Parijs, daarna in den Haag het archaeologische ijzer voor Java te vuur te hebben gelegd, dat toen gesmeed is kunnen worden".

IJzerman gaf, zichzelf op den achtergrond houdend, van een en ander verslag in eene vergadering van het Kon. Aardrijkskundig Genootschap. „De arbeid der opnemingscommissie” — zeide hij aan het slot — ,zal gepubliceerd worden door het Kon. Instituut voor de T. L. en Volkenkunde van Nederlandsch-Indië, dat daartoe eene commissie uit zijn midden aanwees, waarvan Prof. Kern voorzitter en de heer G. P. Rouffaer secretaris is, zoodat verwacht mag worden, dat wij over eenige jaren een standaardwerk over de oude Hindoekunst op Java rijk zullen zijn, dien schat ten volle waardig".

Onder de vleugelen dezer commissie groeide in 1913 uit deze opneming de Oudheidkundige Dienst voor Ned. Indië. Gelijk IJzerman bij het scheppen van de eerste organisatie het zwaartepunt der verwerking van het in beeld gebrachte heeft gelegd in Den Haag, bij de zgn. Commissie van Bijstand, waarvan Rouffaer de hoogst verdienstelijke secretaris is geweest, zoo is IJzerman het in 1921 geweest, die, toen de Oudheidkundige Dienst op Java tot vollen wasdom was opgegroeid, zijn lidmaatschap van de Commissie van Bijstand heeft neergelegd: voor het voortbestaan dier Commissie bestond z.i. geen voldoenden grond meer, de leiding was over te laten aan den deskundige ter plaatse, deze had de verantwoordelijkheid te dragen.

\section{XI.}

In de Commissie van Bijstand was Rouffaer de spil, waarom de arbeid in Nederland draaide. Bij het Koninklijk Instituut was IJzerman met hem in aanraking gekomen en een nawwe relatie ontstond. IJzerman waardeerde de ,onuitputtelijke kennis en den diepen speurzin, de schitterende woordenkeus en de machtige verbeeldingskracht" van Rouffaer, diens toewijding aan de wetenschap en enthousiasme. In Rouffaer vond hij iemand, dien het werk kon worden overgelaten, in zekeren zin ook iemand dien hij slechts behoefde aan te vullen en die uitdrukking kon geven op een wijze, die hem minder goed afging. 
Wat IJzerman aan kennis begeerde te bezitten, maakte hij zich eigen, daarbij zich verzekerende van de kundigste krachten, welke in zijn bereik lagen. In Padang liet hij zich in het Latijn op weg brengen uit Nepos; Poensen koos hij zich, toen hij uit de Babad Tanah Djawi zelf wilde lezen, wat de Javanen van hun historie hadden gemaakt. Toen hij bij de uitgaaf van reisjournalen voor de Van Linschotenvereeniging de wenschelijkheid inzag om zich in de Spaansche en Portugeesche archieven te oriënteeren, maakte hij zich die talen eigen, en ter dege. Bij de velerlei werkzaamheden, die zijn bemoeienis eischten of belangstelling hadden gaande gemaakt, kon hij zich echter niet onafgebroken aan een taak zetten, en, al kon hij veel ondervangen door helpers, die zijne studiën voorbereidden of gedeeltelijk uit de hand namen, - daarnaast had hij in Rouffaer een helderen geest, en groote werkkracht, die uit het gemeenschappelijk arbeidsveld rijken schat kon te voorschijn brengen. Toen IJzerman voorzitter was van het Kon. Aardrijkskundig Genootschap - hij is dat 20 jaar lang geweest -, wist hij Rouffaer in 1906 te vinden om als secretaris der Commissie van Redactie van het Tijdschrift op te treden. En niets is hem liever geweest om diens zaak te bevorderen dan het Kon. Aardrijkskundig Gen. in het belang der ontdekkingsreis in Oost-Indië, welke Rouffaer op aanbeveling van Van Deventer, Groeneveldt en Snouck Hurgronje ging aanvaarden, te bewegen een belangrijk bedrag daarvoor beschikbaar te stellen, bij welk initiatief de Regeering zich kon aansluiten.

De reis werd door Rouffaer's geknakte gezondheid afgebroken. IJzerman haalde in 1911 den doodzieken man te Marseille af en bracht hem naar Holland; als een vader heeft hij voor Rouffaer gezorgd. Het zou niet de eenige keer blijven; in 1928 heeft IJzerman met liefderijke zorg de beschikkingen helpen nemen, welke ter verpleging van Rouffaer noodzakelijk waren geworden. Aan Rouffaer droeg hij op het derde deel van „De Eerste Schipvaart der Nederlanders naar Oost-Indië", dat zij samen op touw hadden gezet, en waarvan toen de beëindiging aan IJzerman toeviel.

\section{XII.}

Op staatkundig gebied is IJzerman voor het publiek niet op den voorgrond gekomen. Lid van de Liberale Unie kwam hij voor Amsterdam IV in de plaats van Cremer in 1906 in de Tweede Kamer. Bij de Atjeh-quaestie over het beleid van den Generaal Van Daalen 
en den Landvoogd, kwam hij krachtig op voor Van Heutsz als brenger van geheel Indië, de Buitenbezittingen ingesloten, onder de heerschappij van orde en rust, maar tevens zou hij wenschen, dat de hoofden krachtig door ons zouden worden gesteund, dat dezen zouden zijn de steun voor het scherm, waaronder de bevolking rust en veiligheid kon vinden. Man van de werkelijkheid, betoogde hij in de zaak van de invoering van de belasting op Sumatra's Westkust, waarbij bloed gevloeid had, dat het verkeerd was om te twisten over het karakter van het daarmede in strijd geachte zgn. Plakaat-pandjang, dat in den loop der tijden voor verreweg het grootste gedeelte reeds was uitgewischt: ,het ging slechts om de vervanging van eene onbillijke belasting (nl. de verplichte koffiecultuur) door een billijke".

In 1909 werd IJzerman bij de verkiezingen vervangen door Van Hamel, en het duurde tot 1917 toen hij in de Tweede Kamer terugkwam; het was ditmaal voor 's-Gravenhage, waar hij woonde in Huize Oosterbeek. Practisch was zijne motie bij de begrooting voor 1917 om ten opzichte van de tot het landsdomein terug te brengen Particuliere Landerijen op Java niet uitsluitend aan te houden op ,aankoop” noch op ,,onteigening”, het best, snelst en het goedkoopst was het, naar gelang van de omstandigheden de eene of de andere wijze toe te passen. Daarvan is ruim gebruik gemaakt, aankoop of liever overneming werd regel. Bij de begrooting voor 1918 diende hij eene motie in, welke gericht was tegen het uit Indië aanbevolen plan om den dienst van het Mijnwezen, welke ,feitelijk” zelfstandlig was, te splitsen in twee dienstvakken - één opsporingsdienst en een dienst der mijnverordeningen - en vervolgens te stellen onder den Directeur van Gouvernementsbedrijven. „Het mijnwezen - merkte IJzerman scherp op - is één en moet één blijven, de verdeeling in allerlei korpsjes is uit den booze. Wat wil men met die zes heeren, die allen op zichzelf staan? Een corps moet een chef hebben, een centrum". En de Kamer gaf IJzerman gelijk.

Wat bij de Inlandsche beweging hij het eerst noodig achtte, bewees hij weldra buitenaf.

Toen bij den al langer durenden wereldoorlog ook voor Java dreigende wolken aan den gezichtseinder schenen op te rijzen, begon een gevoel van onveiligheid zich van de Europeesche kolonie meester te maken. Dat voor de handhaving der neutraliteit de Marine een zware taak te vervullen had, dat deze, correct optredend - bezadigd maar onversaagd -, toch als het ware steeds ,klaar voor het gevecht" moest kunnen zijn, en dat bij de aanwezige zwakke middelen ieder 
zeeman letterlijk zijn leven waagde voor het vaderland, wist op Java zoo goed als iedereen. Dat, wanneer Nederland in den Europeeschen oorlogsmaalstroom werd getrokken, Java bedreigd zou kunnen worden met een inval, welken het met eigen krachten zou hebben te weerstaan, was voor niemand verborgen, doch evenmin, dat het met de middelen bedroefd gesteld was, en men was er niet zoo gerust op, dat op eene behoorlijke verdediging kon worden vertrouwd. Om in het moederland de opvatting te versterken, dat de kolonie, zich met Nederland één gevoelend, handhaving van het Nederlandsch gezag voorstond in het belang van voortgaande ontwikkeling op stoffelijk en geestelijk gebied, - daartoe strekte de Indië Weerbaar-beweging, waartoe in 1917 eene gemengde deputatie naar Nederland vertrok. De samenstelling daarvan — het was niet onbekend - was niet homogeen : een gedeelte was ,,imperialistisch” een ander ,nationalistisch”, het was ook niet de geheele bevolking van Ned. Indië, welke achter deze beweging stond, doch als uiting van het saamhoorigheidsgevoel werd in Holland die stem warm toegejuicht. De handel deed meer: den 30 en Mei had in het gebouw der Nederlandsche Handelmaatschappij eene bijeenkomst plaats, waarin het Comité, dat zich gevormd had met het doel om de oprichting in Nederlandsch-Indië van eene polytechnische school te bevorderen offcieel daarvan mededeeling zou doen aan de deputatie. Bij de plechtigheid waren onder meer aanwezig de oud Gouverneur-Generaal Van Heutsz en de oud President van de Ned. Handelmaatschappij tevens oud-Minister Cremer; de voorzitter van het Comité de President van de Handelmaatschappij Van Aalst voerde het woord. Ook IJzerman maakte deel uit van het Comité, en het is wel niet in de laatste plaats hij geweest, die de keuze van het aan Indië te geven geschenk had bepaald op eene technische hoogeschool; wat Indië bovenal voor haar toekomst noodig had, waren: voor de bevordering van welvaart opgeleide bezonnen mannen, en de exacte wetenschap was meer dan eenige andere daarvoor in de eerste plaats aangewezen. Eerlang ging het presidium over op IJzerman, Van Aalst werd eere-voorzitter, en IJzerman is het ook geweest, die als afgevaardigde van het in Nederland opgerichte Instituut voor Hooger Technisch Onderwijs in Ned. Indië, de reis naar Java tot afwikkeling der plannen en oprichting van de hoogeschool op eene nader te bepalen plaats ondernam. Er bestond op Java een krachtig element, dat voor het tegenwoordige noodig achtte eene opleiding niet die van de Delftsche ingenieurs, doch van een technicum. De Javasche Technisch Onderwijs-Commissie had geadviseerd 
de technische hoogeschool te vestigen te Batavia. Beide hoofdzaken kwamen aan de orde bij de conferentie ten Paleize Weltevreden, waar in den avond van den 1sten Mei 1919 de beslissing viel: merkbaar ongeduldig over de onzekerheid, welke over de gedachtenwisseling hing, maakte IJzerman daaraan een einde, door met den inzet van de hem gegeven volmacht kort en bondig de vraag stellen, of, waar zijn keus bepaald was op de Technische Hoogeschool te Bandoeng, hij op de medewerking der Regeering zou kunnen rekenen. Daarmede was de onderhandeling beslist.

In het IJzerman-park te Bandoeng staat het door Prof. Odé ontworpen borstbeeld van den man, die bij de instelling van het Technisch Hooger Onderwijs in Ned. Indië van den aanvang af de leiding heeft gehad. Bij de overdracht van de Hoogeschool aan het Land bood IJzerman den voorzitter van de faculteit een ambtsketen aan, teeken opnieuw van IJzerman's liefde voor zijn vak en voor Indië.

\section{XIII.}

De eerbewijzen waren niet uitgebleven : Ridder in de orde van den Nederlandschen Leeuw was hij geworden wegens zijn ontdekkingstocht „Dwars door Sumatra”, Groot-Officier in de orde van OranjeNassau werd hij toen de Bandoengsche Hoogeschool aan de Regeering van Nederlandsch-Indië werd overgedragen. De Universiteit te Amsterdam benoemde hem in 1920 tot doctor honoris causa in de Nederlandsche letteren, de Technische Hoogeschool te Bandoeng tot doctor h. c. in de Technische Wetenschap. In 1922 werd IJzerman eerelid van het Kon. Instituut van Ingenieurs, in hetzelfde jaar van het Kon. Aardrijkskundig Genootschap, toen hij na een 20-jarig voorzitterschap den hamer nederlegde, die door zijn medewerker uit den Padangschen tijd en trouwen vriend Delprat zou worden overgenomen. Het was bij zijn aftreden, dat de ondervoorzitter van het Algemeen Bestuur Dr. H. F. R. Hubrecht, dank zeggend voor zijne ,kalme zakelijke leiding”, hem de gouden Plancius-medaille overhandigde, de eerste. Bij herhaling verkeerde IJzerman later nog in dien hem lief geworden kring, waar hij de grootste waardeering genoot.

In het Koninklijk Instituut maakte hij sinds 1901 deel uit van de leden, die periodiek het bestuur vormden, gezien en gewaardeerd om zijn oordeel en zijn tact. Toen Hoetink voorstelde om het driehonderdjarig bestaan van de stad Batavia (30 Mei 1919) te gedenken 
door eene zoo volledig mogelijke uitgaaf van de brieven, besluiten en andere papieren, afkomstig van Batavia's stichter Jan Pietersz. Coen, nam IJzerman niet alleen deel aan het advies daartoe maar ook was hij het, die bij den Minister van Koloniën den weg effende tot het verkrijgen van eene onontbeerlijke subsidie; vertrouwend op zijn wetenschappelijken zin waren de bewindsmannen bij herhaling IJzerman gaarne ter wille, wanneer hij om geldelijken steun aanklopte. In diezelfde periode viel de uitgaaf van Dr. Krom's archaeologische beschrijving van den Boroboedoer. Hij bepleitte de wenschelijkheid om aan Dr. Krom te doen opdragen een werk over de Oude Geschiedenis van Java tot omstreeks 1500 A. D. samen te stellen, - een arbeid, waarmede deze geleerde de wetenschap een belangrijken dienst heeft bewezen. Tezelfder tijd was binnengekomen het door Prof. Krom samengestelde werk over Hindoe-Javaansche kunst, tot de uitgaaf waarvan het Instituut werd verzocht de zorg op zich te nemen en ter perse was de eveneens door Dr. Krom bezorgde uitgaaf van de Nagarakrtagama, - dat alles verbrak de verhouding tusschen de inkomsten en uitgaven zoozeer, dat, zelfs bij de royale wijze waarop door het Ministerie van Koloniën de behulpzame hand werd geboden, de moeilijkheden de krachten van het Instituut te boven dreigden te gaan. IJzerman is het toen geweest, die het penningmeesterschap heeft aanvaard, en aan het Instituut een geldelijken grondslag heeft verzekerd, waarvoor blijvende erkentelijkheid is verschuldigd. Niet alleen - merkte de toenmalige voorzitter Prof. Mr. C. van Vollenhoven op - was de Heer IJzerman voorgegaan in mildheid, maar het doel dat hij zich had gesteld, had hij slechts kunnen bereiken door eene toewijding en inspanning, welke hem aanspraak gaven op de waardeering van allen wien de bloei van het Instituut ter harte ging. In de Buitengewone algemeene vergadering van 19 Februari 1921 werd bij acclamatie besloten het eerelidmaatschap van het Instituut aan te bieden aan die leden, welke door hun milde gift er toe hadden bijgedragen het voortbestaan van het Instituut te verzekeren, de Heeren Mr. A. Cappadose, H. W. A. Deterding, Jhr. H. Loudon en Dr. J. W. IJzerman.

Aan zijne tot energie prikkelende vasthoudendheid is het niet in de laatste plaats te danken, dat na jarenlange voorbereiding het in 1930 gekomen is tot de voltooiing van de Boroboedoer-uitgaaf door de bouwkundige beschrijving, waarvan de Heer Van Erp de samenstelling op zich had genomen. Het proefblad, waarbij dit deel kon worden opgedragen aan ,den Ontdekker van Barabudur's bedolven 
voet", heeft hem bereikt op zijn tachtigsten verjaardag. Hij vierde dezen aan de zijde van zijne tweede echtgenoote, die hem een gelukkig thuis jaren aan jaren verzekerde, een schoone dag in den familiekring, stil te Antwerpen gevierd, - de avond van een in alle richtingen welbesteed leven, waarin opgewektheid, beheerscht gevoel en intuitie bij helder oordeel hem onafscheidenlijk zijn bijgebleven.

\section{XIV.}

Toen IJzerman overleed, had hij nog niet de laatste hand gelegd aan het vierde en laatste deel van de journalen, documenten en andere bescheiden, welke betrekking hadden op Corn. de Houtman's Eerste Schipvaart der Nederlanders naar Oost-Indië. Voor zoover zijne werkzaamheden het toelieten, werkte hij daaraan, zoowel thuis als op het Rijksarchief, waar een kamer te zijner beschikking stond, al sinds jaren. Het werk verscheen in de Linschoten-vereeniging, de Nederlandsche Hakluyt-Society, welke naar een suggestie van Hotz door Wouter Nijhoff in 1908 werd opgericht. Onder de donateurs komt aanstonds voor IJzerman's naam, lid van het bestuur werd hij in de plaats van Rouffaer het daaropvolgende jaar. ,Reeds vóór zijn vertrek naar Oost-Indië, in April 1909, had Rouffaer - schreef IJzerman - den wensch uitgesproken, de bewerking van Willem Lodewycx' ,d' Eerste boeck" voor de jonge Linschoten-vereeniging op zich te nemen, en na zijn terugkeer haastte hij zich, zoodra hij voldoende op krachten gekomen was, met geestdrift die taak ter hand te nemen". Het is wel aardig het verschil in opvatting tusschen Rouffaer en IJzerman bij de bewerking te aanschouwen. IJzerman schreef aan Rouffaer, ,in een briefkaart van 1 October 1912: Geheel deel ik Uw gevoelen, dat het wenschelijk is, zoo kort mogelijke noten te maken; ik zou zeggen zelfs zoo min mogelijk in getal”, - Rouffaer begon de eerste bladzijde van het ,Totten leser” met drie uitvoerige noten, en de volgende bladzijde is reeds voor drie kwart door aanteekeningen ingenomen. Op Rouffaer's verzoek deed IJzerman het zijne, ,toen verschillende onderzoekingen te doen waren in het Rijksarchief en elders, om den arbeid voortgang te doen hebben", maar hij bleef op den achtergrond, liet Rouffaer de vrije hand. Dit werk is een monument van eruditie, historisch en bibliografisch, langzaam vorderend. Het is IJzerman in de gedachte gebleven, toen hij in Indië vertoefde; hij bezocht Bantam, waar hij tot behoud van de over- 
blijfselen van het fort Speelwijk en de oude kota eene beschikking van de Regeering wist te verkrijgen; verder Bali tot het opzoeken van Lintgens' raadselachtigen muur bij het strand van Laboehan Amoek; op Java Padjang, bij welk onderzoek de toenmalige Contr. B. B. Jonquière hem behulpzaam was. In allerlei richtingen liet hij navorschen of stelde hij zelf onderzoek in; de reis naar Portugal in het voorlaatste jaar zijns levens was daaraan dienstbaar. Hij kende zoo goed als alle schepelingen van de Eerste Schipvaart in hun gansche leven, voorzoover het na te speuren viel. Gestadig overlegde hij in zijn geest, of de oorspronkelijk gegeven voorstelling van de motieven, welke tot deze kloeke onderneming hadden geleid, konden worden aanvaard; kooplieden beijveren zich niet altijd om het publiek inzage te geven van bedrijfsgeheimen. Ook is niet alles helder, wat op den tocht heeft plaats gevonden, de hedendaagsche critiek dient aangewend te worden bij de verhalen der belanghebbenden. Bij het dossier van Van Boninghen teekende IJzerman aan: „Bij het lezen van deze brieven en bescheiden krijgt men geen verheffenden indruk. Twist en tweedracht zijn aan de orde van den dag; brooddronkenheid en aan muiterij grenzende weerspannigheid kenmerken den geest, die veelal op de schepen heerscht. Maar het wonderlijke daarbij is, dat de mannen, die, voor zoover zij naar voren treden, zich bij nadere kennismaking zoo zelden onderscheiden door grootheid van karakter of door handelingen, welke onze bewondering of zelfs onze bijzondere sympathie wekken, toch te zamen een reuzentaak hebben verricht en den naam van hun land en hun volk groot hebben gemaakt in de oogen van het overige Europa”.

Eenzelfden indruk ontvangt men van Olivier van Noort, wiens reis om de wereld door IJzerman, voorafgegaan door voortreffelijke inleidende hoofdstukken, mede in de Linschoten-vereeniging werd uitgegeven. Denzelfden indruk ook bij de belegering van het fort Jacatra (22 Dec. 1618-1 Febr. 1619), waarvan de geschiedenis door IJzerman in de Bijdragen werd behandeld, - indien het werk van kleine menschen met al hun gebreken zoozeer blijkt te kunnen bijdragen tot het vervullen van een groote taak, hoeveel te meer moet dat niet het geval zijn bij mannen van groote geestkracht en helder inzicht. 
Thans is dit rijke leven voorbij.

Toen te Westerveld op den 13en October 1932 de lijkkist langzaam daalde - op verzoek van den overledene werden geene redevoeringen uitgesproken —, speelde het orgel :

Uren, maanden, dagen, jaren, vliegen als een schaduw heen, Ach, wij vinden, waar wij staren, niets bestendigs hier beneên.

$\mathrm{OP}$ den weg, dien wij betreden, staat geen voetstap, die beklijft,

Al het heden wordt verleden, schoon 't ons toegerekend blijft.

Zijne goede daden behouden nochtans hunne nawerking; zij zijn evenzoovele blinkende, stalen schakels in den oneindigen keten, welke gesmeed wordt tot verbinding van Nederland en zijne koloniën. 
